\title{
Effects of Cattle-Cud Digester on Soil Properties and Yield of Sweet Potato on Acid Sand of Akwa Ibom State, Nigeria
}

\author{
I. D. Edem and U. C. Udo-inyang \\ Department of Soil Science and Land Resources Management, University of Uyo, Uyo, Akwa Ibom State, Nigeria \\ Email: dennis.edem@gmail.com
}

\begin{abstract}
The knowledge of the physical and chemical properties of the soil can be used in developing best management practices for sustainable soil quality and maximum crop yield. This study was carried out in Uyo, Nigeria to determine the effect of cattle-cud digester on soil properties and yield of sweet potato on acid sand of Akwa Ibom State, Nigeria. The experiment employed a randomized complete block design. The treatment included four rates of cattle cud digester $(0,10,20$ and 30 tons ha-1) in three replications. Sweet potatoes were planted in the experimental units which measured $9 \mathrm{~m} 2$ each at the spacing of $1 \mathrm{~m} \times 0.5 \mathrm{~m}$, at one vine per stand, giving a total of 18 plants per plot. Soil data for the determination of physical and chemical properties were collected at the preplant, mid-plant and at harvest. Data of yield of sweet potatoes were also collected. Analysis of Variance was used for assessing the data collected and correlation analyses were also performed to determine the relationships between soil and crop parameters studied. Results showed that the different rates of cattle-cud digester showed statistically similar bulk densities and total porosities at the three stages of soil study, though apparently, highest bulk densities were recorded with M0 with decreases in bulk densities being observed as the rate of mulch application increased; Ksat recorded with $0 \mathrm{t} /$ ha cattle-cud mulch (M0) application rate was apparently lower than that of $30 \mathrm{t} / \mathrm{ha}$ cattlecud mulch (M30) application rate with the general trend suggesting an increase in Ksat with increase in cattle cud digester rates. Organic matter $(\mathrm{OM})$ content was affected by cattle cud mulch application with the rate obtained with M10 (3.60\%) and M20 (3.04\%) being significantly higher than that of M0 (2.96\%). Based on the findings, it was recommended among others, that farmers should adopt no till method of seed bed preparation in arable crop production as this approach preserves the soil structure and improves infiltration and hydraulic conductivity thereby improving the water availability to the rooting zone.
\end{abstract}

Keywords: physico-chemical properties, nutrient enrichment, potato, mulch, tillage

\section{Introduction}

Holistic management of arable soil is key to dealing with the most complex, dynamic, and interrelated soil properties, thereby maintaining sustainable agricultural production systems. Different cropping systems have different effects on the soil ecosystem (Alam, et al. 2014). Arriaga and Lowery (2017) stated that conventional agriculture production systems are chemical and tillage-intense and as such soil health in these systems is not optimal. However, good management practices which include crop rotations, cover crops, and reduced tillage will yield positive economic and environmental benefits to soil ecosystem.

Mulching is an agricultural practice that enhances the soil condition. According to Peace (2015), mulching is one of the numerous soil improvement techniques that can be used by farmers to improve their soil with great efficacy; when carried out properly it can increase the output of the planted crops tremendously. Mulching helps to control annual weeds, conserve soil moisture, reduce soil erosion by reducing the impact of raindrops and water runoff, reduce the severity of some diseases such as blights on tomatoes, keep fruits vegetables and flowers free of rain-spattered soil, reduce fruit and vegetable spoilage, moderate soil temperatures and provide an attractive background for plantings (Jauron, 2013). Organic mulch reflects solar radiation thereby keeps soil cooler, increase the amount of water that soaks into the soil leading to more water in the soil means more water for the crops, suppresses weed 
germination, improves the water-holding capacity of the soil, maintains a more even soil temperature and create a very good porous soil (Telkar, et al 2006).

Mulch helps to preserve high and sustainable yields by increasing the soil organic matter (SOM) content and therefore improving soil physical quality (Jordán, et al 2011). Kar and Kumar (2007) found out that the application of straw mulch significantly increased the available phosphorus and potassium in the soil. Ogban, et al (2016) carried out a study to evaluate the effect of incorporated, surface, and bare (control) residue mulching methods on soil properties and maize growth and yield and concluded that incorporating residue mulch may improve soil physical and chemical properties and increase crop production in south-eastern Nigeria. Jordan, et al (2010) found out that mulching application significantly improved physical and chemical properties of the studied soil with respect to control, and the intensity of changes was related to mulching rate. The organic matter content was generally increased, although no benefit was found beyond $10 \mathrm{Mg} \mathrm{ha}^{-1}$ year $^{-1}$. Bulk density, porosity and aggregate stability were also improved with increasing mulching rates, which confirmed the interactions of these properties.

There were no significant differences in the values of soil moisture content, soil temperature, porosity and bulk density between Omuo and Kabba sites when reported by Adebisi et al (2016) who studied the effect of tillage and mulch combinations on soil physical and chemical properties and sweet potato (Ipomoea batatas L.) performance.

Sweet potato is one of the major sources of food, animal feed and industrial raw materials and has a significant contribution as an energy supplement and phytochemical source of nutrition (Esan and Omilani, 2018). It is a nutritious root crop that contains significant amounts of fiber, beta carotene and vitamin C, particularly in varieties with highly colored roots (Brandenberger, et al 2014). London and Walder (2018) opined that sweet potatoes are sweet, soft, and total nutrition powerhouses and are loaded with vitamins, minerals, fiber, and health-promoting phyto nutrients. If given the right growing conditions, sweet potato has the potential to produce remarkably high yields and can also yield more reliably under unfavourable conditions than many other crops (Stathers, et al 2018). According to Adebisi et al (2016), the application of mulch was found to increase the yield components of sweet potato compared with no mulch application and the increase in yield as mulch rates increases was attributed to increase in soil organic matter from the mulch.

The study made use of an organic material that is seemingly ignored - cattle-cud. The cattle-cud digester is portion of feed that is found in the rumen. The rumen is the largest compartment, and it contains billions of bacteria, protozoa, molds, and yeasts (Hall and Silver, 2009). While in the rumen, the partly digested feed is acted upon by rumen microbes which ferment the feed and make volatile fatty acids, B vitamins, vitamin K and amino acids (Linn et al. 2018). The cattle-cuds are discarded in heaps in abattoirs and their incessant handling might constitute a hazard to the environment where they are dumped. There is limited research study on the implications of cattle-cud digester as mulching materials on soil properties and performance of sweet potato in southeast Nigeria. Hence, the study aimed at determining the effect of cattle-cud digester on soil properties and yield of sweet potato on acid sand of Akwa Ibom State, Nigeria.

\section{Materials and Methods}

\subsection{Study Area}

A field studies was conducted in Uyo, Akwa Ibom state, south eastern Nigeria. The area is characterized by a tropical climate which is controlled by high rainfall. Uyo has a mean annual rainfall of about $2484 \mathrm{~mm}$, mean annual temperature of $27^{\circ} \mathrm{C}$, with varying relative humidity through the year from $70-80 \%$ (climate - data.org, 2016). The climatic factors favour luxuriant tropical rainforest, which has been almost replaced by secondary forest of predominantly wild oil palms, woody shrubs like siam weed (Chromolaenaodorata), plantain plantations and various grass undergrowth. The State lies between latitude $04^{\circ} 32^{\prime}$ and $05^{\circ} 33^{\prime}$ north and longitude $07^{\circ} 25^{\prime}$ and $08^{\circ} 25^{\prime}$ east and is underlain by one geological formation, the coastal plain sands comprising largely poorly consolidated sands (Udosen, 2012). 


\subsection{Field Experiment}

The experimental site was cleared manually. Experimental plots were mapped out for a $2 \times 4$ factorial experiment with three replications. The experiment employed a randomized complete block design. The treatment included four rates of cattle cud digester $\left(0,10,20\right.$ and 30 tons $\left.\mathrm{ha}^{-1}\right)$ in three replications. Sweet potatoes vines measuring $25 \mathrm{~cm}$ each were planted in the experimental units which measured $9 \mathrm{~m}^{2}$ each at the spacing of $1 \mathrm{~m} \times 0.5 \mathrm{~m}$, at one vine per stand, giving a total of 18 plants per plot. The cured cattle-cud digester was applied one week after planting. Weeding was carried out manually.

\subsection{Procurement of Materials}

Composite soil samples were randomly taken at depth 0 to $15 \mathrm{~cm}$ based on plots from the experimental sites during pre-planting, mid planting and at harvest. Hybrid sweet potato (TIS 87/0087) vines were obtained from the Research Centre in Michael Okpara University of Agriculture, Umudike. Cattle-cud digester was collected from Ntak Inyang Abbatoir and dried to reduce moisture content and weighed for application rates of 10,20 and 30ton/ha treatments. At harvest, the tuber length, tuber girth, number of tubers and yield were measured.

\subsection{Analytical Methods}

Hydraulic conductivity and bulk density was done using the constant head permeameter method as described by Klute and Dirksen (1986) and Gulser and Candemir (2008), respectively. Aggregate analysis was done using the wet sieve method; Soil $\mathrm{pH}$ and electrical conductivity were measured in 1:2.5 soil and water ratio using a digital $\mathrm{pH}$ meter (Mclean, 1982) and conductivity bridge (Rhoades, 1996), respectively. Organic carbon was determined using Walkley and Black wet oxidation method (Nelson and Sommers, 1982); Organic Total nitrogen was determined using micro kjeldahl digestion and distillation method (Bremner and Mulvaney, 1982).

Available phosphorus was extracted by Bray p-1 method of Bray and Kurtz as described by Kuo (1996) and phosphorus in the extract was obtained by blue colour method of Murphy and Riley (1962). Exchangeable bases were extracted using $1 \mathrm{~N}$ ammonium acetate and the solution was used for the determination of calcium and magnesium through EDTA (Ethylene diamine tetra acetic acid) titration as well as sodium and potassium measured by flame photometer. Exchangeable acidity was extracted with one normal potassium chloride solution (1NKCL) and acidity determined by titration as described by Thomas (1996).

\subsection{Statistical Analysis}

Data obtained in the study were subjected to Analysis of Variance (ANOVA) using GenStat (Discovery edition 3) statistical software. Significant means were separated by Duncan Multiple range test (DMRT) at $5 \%$ probability level. Correlation analysis was used to access the relationship between soil properties and yield data.

\section{Results and Discussion}

\subsection{Effect of Different Rates of Cattle-Cud Digester on Some Soil Physical Properties}

Sand particles dominated the experimental soils, with values ranging from 79 to $80 \%$ at the preplanting stage, 79 to $83 \%$ at the mid-planting stage and 85 to $87 \%$ at the harvest whereas the content of clay and silt particles were lower. Soil particle sizes were not significantly affected by different rates of cud-mulch treatments. The texture of the soils before planting was loamy sand and remained unchanged at the pre-plant, mid-plant and harvest stages (Table 1). This can be explained by the fact that soil particle size distribution, which constitutes texture is an inherent soil property and is not affected by soil management (Omenihu and Opara-Nadi, 2015). 
Table 1. Means of some physical properties as affected by cattle-cud digester rate during the pre-planting, midplanting and harvest stages

\begin{tabular}{|c|c|c|c|c|c|c|c|c|c|c|c|c|}
\hline Treatment & Sand & Silt & Clay & Texture & $\mathrm{BD}$ & TP & Ksat & $2 \mathrm{~mm}$ & $1 \mathrm{~mm}$ & $0.5 \mathrm{~mm}$ & $0.25 \mathrm{~mm}$ & MWD \\
\hline \multicolumn{13}{|c|}{ Pre-plant } \\
\hline $\mathrm{M}_{0}$ & 79.88 & 7.67 & 12.45 & Ls & 1.09 & 60.82 & 0.26 & 3.5 & 19.67 & 26.33 & 37.5 & 0.71 \\
\hline $\mathrm{M}_{10}$ & 80.21 & 7.65 & 12.13 & Ls & 0.96 & 63.42 & 0.22 & 3.5 & 19.67 & 24.67 & 33.33 & 0.72 \\
\hline $\mathrm{M}_{20}$ & 79.21 & 8.07 & 12.72 & Ls & 1.03 & 61.23 & 0.28 & 3.83 & 18 & 25.83 & 31.83 & 0.69 \\
\hline $\mathrm{M}_{30}$ & 79.88 & 7.09 & 13.03 & Ls & 0.96 & 63.85 & 0.29 & 3.17 & 20.5 & 26.17 & 38 & 0.74 \\
\hline $\operatorname{LSD}_{(0.05)}$ & NS & NS & NS & & NS & NS & NS & NS & NS & NS & 3.92 & NS \\
\hline \multicolumn{13}{|c|}{ Mid-plant } \\
\hline $\mathrm{M}_{0}$ & 82.52 & 6.03 & 11.45 & Ls & 1.26 & 52.58 & 0.44 & 3.5 & 19.67 & 26.33 & 37.5 & 0.71 \\
\hline$M_{10}$ & 81.9 & 6.75 & 11.36 & Ls & 1.27 & 52.03 & 0.39 & 3.5 & 19.67 & 24.67 & 35.67 & 0.72 \\
\hline $\mathrm{M}_{20}$ & 80.58 & 7.35 & 12.08 & Ls & 1.29 & 51.29 & 0.54 & 3.5 & 18.17 & 25.67 & 33 & 0.69 \\
\hline $\mathrm{M}_{30}$ & 81.99 & 6.51 & 11.51 & Ls & 1.2 & 54.73 & 0.54 & 3.17 & 20.33 & 26.33 & 37.5 & 0.74 \\
\hline $\operatorname{LSD}_{(0.05)}$ & NS & $\mathrm{NS}$ & NS & & NS & NS & $\mathrm{NS}$ & $\mathrm{NS}$ & NS & $\mathrm{NS}$ & NS & $\mathrm{NS}$ \\
\hline \multicolumn{13}{|c|}{ Harvest } \\
\hline $\mathrm{M}_{0}$ & 87.03 & 4.7 & 8.27 & Ls & 1.27 & 52.07 & 0.84 & 0 & 12 & 28.5 & 27.5 & 0.49 \\
\hline $\mathrm{M}_{10}$ & 86.36 & 5.37 & 8.27 & Ls & 1.22 & 53.95 & 0.67 & 0 & 12.5 & 23.33 & 30.67 & 0.48 \\
\hline $\mathrm{M}_{20}$ & 85.69 & 5.37 & 8.93 & Ls & 1.23 & 53.48 & 0.81 & 0 & 12.83 & 28.17 & 30 & 0.52 \\
\hline $\mathrm{M}_{30}$ & 87.41 & 5.03 & 7.61 & Ls & 1.23 & 53.47 & 0.94 & 0 & 11.83 & 27.17 & 32.5 & 0.5 \\
\hline $\operatorname{LSD}_{(0.05)}$ & NS & NS & NS & & NS & NS & NS & NS & NS & NS & NS & NS \\
\hline
\end{tabular}

$\mathrm{M}_{0}=$ Mulch at 0 tonnes/ha, $\mathrm{M}_{10}=$ Mulch at 10 tonnes/ha, $\mathrm{M}_{20}=$ Mulch at 20 tonnes/ha, $\mathrm{M}_{30}=$ Mulch at 30 tonnes $/$ ha, Ls = Loamy sand, BD = Bulk Density, TP = Total Porosity, Ksat = Saturated Hydraulic conductivity, MWD $=$ Mean Weight Diameter, LSD $=$ Least Significant Difference

The different rates of Cattle-cud digester showed statistically similar bulk densities and total porosities at the three stages of soil study (Table 1), though apparently, highest bulk densities were recorded with M0 with decreases in bulk densities being observed as the rate of mulch application increased; this was clearly observed at the pre-plant and harvest stages. Ksat recorded in soils treated with the different rates of cattle-cud digester were not significantly different from each other. At all stages of soil study (Table 1), Ksat recorded with 0 t/ha cattle-cud digester $\left(\mathrm{M}_{0}\right)$ application rate was apparently lower than that of $30 \mathrm{t} / \mathrm{ha}$ cattle-cud mulch $\left(\mathrm{M}_{30}\right)$ application rate with the general trend suggesting an increase in Ksat with increase in cattle cud digester rates.

The addition of cattle-cud mulch increased the organic matter content of the soil, reduced the density of the soil (Ogbodo, 2011; Agbede, et al 2013) and caused the apparent decreasing bulk density and a corresponding increasing total porosity as the application rate of cattle-cud mulch increased. This effect was translated to saturated hydraulic conductivity as soil pore spaces are the conducting channels through which water flows through the soil (Hillel, 2004).

The only significant effect of cattle cud digester rate on aggregate sizes was observed in $0.25 \mathrm{~mm}$ at the pre-planting stage, in which $\mathrm{M}_{30}$ rate showed significantly higher $0.25 \mathrm{~mm}$ aggregate size $(38 \mathrm{~g})$ than those of $\mathrm{M}_{20}(31.83 \mathrm{~g})$ and $\mathrm{M}_{10}(33.33 \mathrm{~g})$. Apparently higher MWD were observed among soils with higher rates of cattle cud digester treatments, though there were no significant effect of cattle cud digester rates on MWD at the three stages of soil study.

\subsection{Effect of Different Rates of Cattle-Cud Digester on Some Soil Chemical Properties}

At the pre-planting stage, post-planting and harvest stages, soil $\mathrm{pH}$ and electrical conductivity were not significantly affected by mulch rate. Soil reactions were generally strong acid (between $\mathrm{pH} 5.1$ and 5.5) apart from the 5.6 (moderate acid) that was recorded with M20 at the mid plant stage (Table 2). There was no significant effect of mulch rate on organic matter content at the pre-plant stage. Available phosphorus concentrations were generally high $\left(>25 \mathrm{mg} \mathrm{kg}^{-1}\right)$ but were not significantly affected by the cattle-cud digester rate at the pre-plant, mid-plant and post-plant stages. Apparent considerations at 
the pre and mid- plant stages however showed available $\mathrm{P}$ to increase as the rate of application of cattle-cud mulch increased. Organic matter and available $\mathrm{P}$ were observed to apparently increase with increasing rates of cattle-cud digester application because of the increase in organic matter input from the cattle-cud digester, which in turns increased the available $\mathrm{P}$ content of the soil (Bot and Benites, 2005).

Mulch rate did not significantly affect the concentration of exchangeable $\mathrm{Ca}, \mathrm{Mg} \mathrm{K}$ and $\mathrm{Na}$ at preplant, mid-plant and harvest stages (Table 2). Generally, Exchangeable Ca was the most dominant basic cation, followed by $\mathrm{Mg}$ and then $\mathrm{K}$ and $\mathrm{Na}$ in that order (Table 2). Total exchangeable bases (TEB), exchange acidity (EA), ECEC and base saturation were mostly not significantly affected by mulch rate at the pre-plant, mid-plant and harvest stages. The concentrations of exchangeable bases ( $\mathrm{Ca}, \mathrm{Mg}, \mathrm{K}$ and $\mathrm{Na}$ ) were not significantly affected by cattle-cud mulch rates and the concentrations obtained did not follow a regular pattern for it to be attributed largely to the effect of the applied cattle-cud mulch due to the variation in native soil concentrations of these basic cations. The insignificant effect of cattle-cud mulch on basic cations can also be linked to the low efficiency of soil nutrient noted when nutrients are applied through organic sources alone (Pypers, et al 2005).

Though there were no significant effect of mulch rate on exchange acidity, apparent considerations show lower exchange acidity values for $\mathrm{M}_{20}\left(1.92 \mathrm{cmol} \mathrm{kg}{ }^{-1}\right)$ and $\mathrm{M}_{30}\left(1.99 \mathrm{cmol} \mathrm{kg}^{-1}\right)$ against the 2.01 cmol kg-1 observed for $M_{0}$ and $M_{10}$. At the harvest stage, $M_{20}$ and $M_{30}$ also recorded exchange acidity values that were lower than that of $\mathrm{M}_{10}$ (Table 2 ). The apparent decrease in soil acidity with increase in the rate of cattle-cud digester found in the study could be attributed to the efficacy of the cattle-cud in reducing soil acidity. The analysis of the cattle-cud mulch showed that it was alkaline mulch (Table 7), thus the ability to reduce soil acidity.

Table 2. Means of some chemical properties as affected by tillage and cattle-cud mulch rate during the preplanting, mid-planting and harvest stages

\begin{tabular}{|c|c|c|c|c|c|c|c|c|c|c|c|c|c|}
\hline Treatment & pH & EC & $\mathrm{OM}$ & TN & Av.P & $\mathrm{Ca}$ & $\mathrm{Mg}$ & $\mathrm{Na}$ & K & TEB & EA & ECEC & BS \\
\hline \multicolumn{14}{|c|}{ Pre-plant } \\
\hline $\mathrm{M}_{0}$ & 5.24 & 0.06 & 2.96 & 0.08 & 50.88 & 8.2 & 2.32 & 0.05 & 0.1 & 10.66 & 1.87 & 12.53 & 83.82 \\
\hline $\mathrm{M}_{10}$ & 5.25 & 0.09 & 3.6 & 0.09 & 60.55 & 9 & 2.37 & 0.06 & 0.1 & 11.53 & 1.9 & 13.43 & 84.56 \\
\hline $\mathrm{M}_{20}$ & 5.36 & 0.06 & 3.04 & 0.07 & 63.55 & 9.32 & 2.4 & 0.05 & 0.1 & 11.86 & 1.9 & 13.74 & 85.66 \\
\hline $\mathrm{M}_{30}$ & 5.19 & 0.06 & 2.84 & 0.07 & 61.77 & 7.93 & 2.03 & 0.05 & 0.1 & 10.11 & 1.88 & 11.99 & 83.54 \\
\hline $\operatorname{LSD}_{(0.05)}$ & NS & NS & 0.47 & $\mathrm{NS}$ & NS & NS & NS & NS & $\mathrm{NS}$ & NS & NS & NS & NS \\
\hline \multicolumn{14}{|c|}{ Mid-plant } \\
\hline $\mathrm{M}_{0}$ & 5.48 & 0.06 & 2.62 & 0.07 & 59.55 & 10.2 & 2.91 & 0.06 & 0.11 & 13.32 & 2.01 & 15.33 & 86.36 \\
\hline $\mathrm{M}_{10}$ & 5.34 & 0.06 & 2.87 & 0.07 & 73.66 & 10.5 & 2.92 & 0.06 & 0.11 & 13.57 & 2.01 & 15.58 & 86.85 \\
\hline $\mathrm{M}_{20}$ & 5.6 & 0.06 & 2.86 & 0.07 & 74.45 & 10.5 & 3.08 & 0.06 & 0.11 & 13.7 & 1.92 & 15.53 & 87.31 \\
\hline $\mathrm{M}_{30}$ & 5.46 & 0.07 & 2.94 & 0.09 & 68.11 & 9.94 & 2.91 & 0.06 & 0.11 & 13.01 & 1.99 & 14.95 & 86.6 \\
\hline $\operatorname{LSD}_{(0.05)}$ & NS & $\mathrm{NS}$ & NS & $\mathrm{NS}$ & NS & NS & NS & NS & $\mathrm{NS}$ & NS & NS & NS & $\mathrm{NS}$ \\
\hline \multicolumn{14}{|c|}{ Harvest } \\
\hline $\mathrm{M}_{0}$ & 5.47 & 0.07 & 3.07 & 0.08 & 48.69 & 10 & 2.62 & 0.07 & 0.1 & 12.79 & 1.84 & 14.59 & 87.59 \\
\hline $\mathrm{M}_{10}$ & 5.52 & 0.09 & 2.95 & 0.07 & 42.75 & 9.06 & 2.55 & 0.06 & 0.1 & 11.77 & 2.34 & 13.6 & 86.36 \\
\hline $\mathrm{M}_{20}$ & 5.48 & 1.44 & 3.24 & 0.08 & 41.04 & 9.26 & 2.62 & 0.06 & 0.09 & 12.03 & 1.8 & 13.83 & 87.18 \\
\hline $\mathbf{M}_{30}$ & 5.5 & 0.08 & 3.24 & 0.08 & 43.51 & 9.25 & 2.59 & 0.07 & 0.09 & 11.99 & 1.84 & 13.83 & 86.7 \\
\hline $\operatorname{LSD}_{(0.05)}$ & NS & NS & $\mathrm{NS}$ & $\mathrm{NS}$ & NS & NS & NS & $\mathrm{NS}$ & NS & NS & $\mathrm{NS}$ & NS & NS \\
\hline
\end{tabular}

$\mathrm{M}_{0}=$ Mulch at 0 tonnes/ha, $\mathrm{M}_{10}=$ Mulch at 10 tonnes/ha, $\mathrm{M}_{20}=$ Mulch at 20 tonnes $/$ ha, $\mathrm{M}_{30}=$ Mulch at 30 tonnes $/$ ha, $\mathrm{EC}=$ Electrical Conductivity, $\mathrm{TN}=$ Total Nitrogen, Av.P = Available Phosphorus, Ca = Calcuim, Mg = Magnesium, $\mathrm{Na}=$ Sodium, $\mathrm{K}=$ Potassium, TEB = Total Exchangeable Bases, EA = Exchange Acidity, ECEC= Effective Cation Exchange Capacity, BS = Base Saturation, LSD = Least Significant Difference

\subsection{Effect of Cattle-Cud Digester Rates on the Tuber Yield of Sweet Potato}

Tuber girth and tuber length of sweet potato were significantly affected by mulch rate. The highest tuber girth of potato $(19 \mathrm{~cm})$ was obtained with $\mathrm{M}_{30}$ which was significantly higher than those of $\mathrm{M}_{10}$ 
and $\mathrm{M}_{20}$, which recorded tuber girths of 14.75 and $13.0 \mathrm{~cm}$, respectively. Similarly, $\mathrm{M}_{30}$ produced the highest tuber length which was equal with that of $\mathrm{M}_{20}$ but significantly higher than that of $\mathrm{M}_{10}$ (Table 3 ). Yield parameters of sweet potatoes generally showed increasing trend with increase in the quantity of cattle-cud digester applied.

Tuber girth, tuber length showed increasing trend with increase in the quantity of cattle-cud mulch applied owing to the increased input of soil nutrient from the applied mulch (Bot and Benites, 2005). However, other yield parameters did not give significant results probably, owing to a similar nonsignificant difference in basic cations (soil nutrients) observed with different cattle-cud mulch rates in this study.

Table 3. Mean tuber yield parameters of sweet potatoes as affected by cattle-cud digester rates

\begin{tabular}{lcccccc}
\hline Treatment & $\begin{array}{c}\text { Tuber } \\
\text { Girth }\end{array}$ & $\begin{array}{c}\text { Tuber } \\
\text { Length }\end{array}$ & Marketable & $\begin{array}{c}\text { Non } \\
\text { Marketable }\end{array}$ & $\begin{array}{c}\text { No of } \\
\text { Tuber }\end{array}$ & $\begin{array}{c}\text { YIELD } \\
\text { (tons ha }^{-1} \text { ) }\end{array}$ \\
\hline $\mathbf{M}_{\mathbf{0}}$ & 13.90 & 18.32 & 28.33 & 28.50 & 56.83 & 2.95 \\
$\mathbf{M}_{\mathbf{1 0}}$ & 14.74 & 16.06 & 16.17 & 15.17 & 31.33 & 1.68 \\
$\mathbf{M}_{\mathbf{2 0}}$ & 16.99 & 18.76 & 23.83 & 18.83 & 42.67 & 2.30 \\
$\mathbf{M}_{\mathbf{3 0}}$ & 19.00 & 21.07 & 32.33 & 27.83 & 60.50 & 4.06 \\
LSD $_{(\mathbf{0 . 0 5})}$ & 2.92 & 3.19 & $\mathrm{NS}$ & $\mathrm{NS}$ & NS & NS \\
\hline
\end{tabular}

$\mathrm{M}_{0}=$ Mulch at 0 tonnes/ha, $\mathrm{M}_{10}=$ Mulch at 10 tonnes/ha, $\mathrm{M}_{20}=$ Mulch at 20 tonnes $/$ ha, $\mathrm{M}_{30}=$ Mulch at 30 tonnes/ha, LSD = Least Significant Difference

\subsection{Relationships between Yield of Sweet Potatoes and Soil Properties and Soil Loss Parameters}

Table 4. Correlations between soil physical properties

\begin{tabular}{cccccccc}
\hline & Sand & Silt & Clay & Ksat & BD & TP & MWD \\
\hline Sand & 1.000 & & & & & \\
Silt & $-.450^{*}$ & 1.000 & & & & \\
Clay & $-.794^{* *}$ & -0.185 & 1.000 & & & \\
Ksat & -0.390 & 0.397 & 0.162 & 1.000 & & \\
BD & 0.128 & 0.306 & -0.352 & -0.032 & 1.000 & \\
TP & -0.131 & -0.211 & 0.292 & 0.233 & $-.941^{* *}$ & 1.000 & \\
MWD & -0.178 & 0.104 & 0.121 & 0.317 & -0.152 & 0.141 & 1.000 \\
\hline
\end{tabular}

Table 5. Correlations between sweet potatoes yield and some soil physical properties

\begin{tabular}{lrrrr}
\hline & YIELD & No of Tubers & Tuber Length & Tuber Girth \\
\hline Sand & -0.021 & -0.193 & 0.112 & 0.262 \\
Silt & 0.074 & 0.066 & 0.142 & 0.005 \\
Clay & -0.027 & 0.168 & -0.217 & -0.289 \\
Ksat & 0.227 & 0.275 & 0.126 & 0.197 \\
BD & -0.018 & -0.105 & 0.113 & 0.136 \\
TP & -0.039 & 0.066 & -0.096 & -0.152 \\
MWD & 0.234 & $.414^{*}$ & 0.026 & 0.323 \\
\hline
\end{tabular}

Ksat - saturated hydraulic conductivity, BD = bulk density,

$\mathrm{TP}=$ total porosity, MWD = Mean Weight diameter

Sand correlated significantly and negatively with silt $\left(\mathrm{r}=-0.450^{*}\right)$ and clay $\left(\mathrm{r}=-0.794^{* *}\right)($ Table 4$)$. Number of tubers correlated significantly and positively with mean weight diameter (MWD) (Table 5). 
Yield and number of tubers of sweet potatoes increased with increase in base saturation $\left(\mathrm{r}=0.456^{*}\right.$ and $0.542^{* *}$, respectively). Tuber length correlated significantly and positively with soil pH (Table 6). The positive correlation of tuber length with soil $\mathrm{pH}$ is due to the fact that as soil $\mathrm{pH}$ increases from acid towards neutral, there is an increase in the availability of basic cations (soil nutrients). It can also be attributed to the favourable conditions offered to microorganisms to grow and perform their functional ecological roles which culminated in increased nutrient availability.

Table 6. Correlations between sweet potatoes yield and some soil chemical properties

\begin{tabular}{lrcrr}
\hline & YIELD & No. of Tuber & Tuber Length & Tuber Girth \\
\hline pH & 0.093 & 0.176 & $0.446^{*}$ & -0.094 \\
OM & -0.019 & -0.013 & -0.069 & -0.243 \\
TN & -0.121 & -0.070 & -0.028 & -0.187 \\
AP & 0.111 & 0.193 & 0.063 & 0.029 \\
Ca & -0.211 & -0.311 & -0.182 & 0.050 \\
Mg & -0.204 & -0.360 & -0.087 & -0.013 \\
K & -0.021 & 0.077 & -0.135 & -0.385 \\
TEB & -0.212 & -0.324 & -0.166 & 0.035 \\
EA & -0.046 & -0.065 & 0.133 & 0.178 \\
ECEC & -0.178 & -0.296 & -0.136 & 0.059 \\
BS & $0.456^{*}$ & $0.542^{* *}$ & -0.278 & -0.193 \\
\hline
\end{tabular}

$\mathrm{OM}$ - organic matter, TN - total nitrogen, AP - available phosphorus, TEB - total exchangeable bases, ECEC - effective cation exchange capacity, BS - base saturation, RWUE - Rainwater use efficiency

Table 7. Chemical composition of cattle-cud

\begin{tabular}{cc}
\hline Element & Composition \\
\hline $\mathrm{pH}$ & 9.58 \\
$\mathrm{EC}(\mathrm{ds} / \mathrm{m})$ & 1.95 \\
$\mathrm{Av} . \mathrm{P}(\mathrm{mg} / \mathrm{kg})$ & 74.10 \\
Org. Carbon $(\%)$ & 35.46 \\
$\mathrm{C} / \mathrm{N}$ & 23.18 \\
Org. Matter $(\%)$ & 61.31 \\
Total N $(\%)$ & 1.53 \\
$\mathrm{Ca}(\mathrm{Cmol} / \mathrm{kg})$ & 12.00 \\
$\mathrm{Mg}(\mathrm{Cmol} / \mathrm{kg})$ & 4.26 \\
$\mathrm{Na}(\mathrm{Cmol} / \mathrm{kg})$ & 2.07 \\
$\mathrm{~K}(\mathrm{Cmol} / \mathrm{kg})$ & 17.73 \\
\hline
\end{tabular}

EC - Electrical conductivity, Org.Carbon - organic carbon, $\mathrm{TN}$ - total nitrogen, Av.P - available phosphorus, $\mathrm{Ca}=$ Calcuim, $\mathrm{Mg}=$ Magnesium, $\mathrm{Na}=$ Sodium, $\mathrm{K}=$ Potassium,

\section{Conclusion and Recommendation}

It can be concluded that cattle-cud digester increased the organic matter content of the soil, reduced the bulk density of the soil and induced a corresponding increase in total porosity and saturated hydraulic conductivity with effect apparently increasing as the application rate of cattle-cud digester increased. There was apparent increase in concentration of available $\mathrm{P}$ with increase in the application rate of cattle-cud mulch. Tuber girth and tuber length showed significant increase with increasing rate of cattlecud mulch application. Though there were no significant effect of cattle-cud mulch on Marketable Tubers, Non Marketable Tubers, Number of Tuber and Yield of Tuber, the general trend was similar to those of tuber girth and tuber length. Following the trend of organic agricultural products, farmers 
should opt for cattle-cud as their choice organic material. This can double as a mulching and a nutrient enriching material and is relatively cheap.

\section{References}

1. Adebisi, S., Adekiya, A.O. and Ojeniyi S.O. (2016). Study into tillage-mulch package for production of sweet potato (Ipomoea batatas L) effect on soil properties and yield. Scientia Agriculturae, 15(2): 361-366

2. Agbede, T. M., Adeyinka, A. O. and Ogeh, S. J. (2013). Effects of Chromolaena and Tithonia Mulches on Soil Properties, Leaf Nutrient Composition, Growth and Yam Yield. West African Journal of Applied Ecology, 21(1): $15-29$

3. Agbede, T. M., and Olasekan, A.A. (2009). Tillage effects on soil properties and performance of sweet potato on an Alfisol in Southwestern Nigeria. American-Eurasian Journal of Sustainable Agriculture, 3(3): 561-568

4. Alam, K. M, Islam, M. M., Salahin, N. and Hasanuzzaman, M. (2014). Effect of Tillage Practices on Soil Properties and Crop Productivity in Wheat-Mungbean-Rice Cropping System under Subtropical Climatic Conditions. Scientific World Journal, 3 http://dx.doi.org/10.1155/2014/437283 (Retrieved on 5th August 2019)

5. Arriaga, F. T. and Birl, L. (2017). Conventional agricultural production systems and soil function. https://doi.org/10.1016/B978-0-12-805317-1.00005-1/09-/25. (Retrieved 20th January, 2019

6. Bot, A. and Benites, J. (2005). The Importance of Organic Matter: Key to Drought-resistant Soil and Sustained Food Production. Food and Agriculture Organization of the United Nations, Rome.

7. Brandenberger, L., Shrefler, J., Rebek, E. and Damicone, J. (2014). Sweet Potatoe Production.

8. https://www.researchgate.net/publication/280948890Sweet_Potato_Production. (Retrieved on 29th April 2019)

9. Bremner, J. M. and Mulvaney (1982). Total Nitrogen, pp 595-624. In: A. L. Page, Miller, R. H.and D. R. Keeney (Editors) Methods of Soil Analysis. Part 2, 2nd edition, Agronomy Monograph 9, American Society of Agronomy, Madison, Wisconsin, 1350p

10. Climate-Data.org (2016). Uyo climate. https://en.climate-data.org/africa/nigeria/akwa-ibom/uyo-4733/. (Retrieved on 5th January 2019)

11. Esan, V. I. and Omilani, O.O. (2018). Assessment of four sweet potato (Ipomea batatas L.) varieties for adaptability and productivity in Iwo, Osun state. Asian Journal of Agricultural and Horticultural Research 1(1): $1-8$

12. Food and Agricultural Organization (2019). Soil erosion: the greatest challenge to sustainable soil management. Rome, 100p http://www.fao.org/3/ca4395en/ca4395en.pdf. (Retrieved on 20th January, 2020)

13. Franzen, H., R. Lal, and W. Ehlers. (1994). Tillage and mulching effects on physical properties of a tropical Alfisol. Soil and Tillage Research, 28:329-346.

14. Gulser, G. and Candemir, F. (2008). Prediction of Saturated Hydraulic Conductivity Using Some Moisture Constants and Soil Physical Properties. https://www.researchgate.net/

15.Publication/228839205_Prediction_of_Saturated_Hydraulic_Conductivity_Using_Some_Moisture_Constants and_Soil_Physical_Properties. (Retrieved on 20th March 2019)

16. Hall, J. B. and Silver, S. (2009). Nutrition and Feeding of the Cow-Calf Herd: Digestive System of the Cow. https://www.pubs.ext.vt.edu/content/dam/pubs_ext_vt_edu/400/400-010/400-010_pdf.pdf. (Retrieved on 20th March 2019)

17. Hillel, D. (2004). Introduction to Environmental Soil Physics. Academic Press, New York.

18. Jauron, R. (2013). Organic mulches. Available at: https://web.extension.illinois.edu/cook/downloads/68887.pdf. (Retrieved on 1st May 2019)

19. Jordan, A., Zavala, L. M. and Gil, J. (2010). Effects of mulching on soil physical properties and runoff under semi-arid conditions in southern Spain. Catena, 81(1): 77-85

20. Jordán A., Zavala L.M., Muñoz-Rojas M. (2011). Mulching, Effects on Soil Physical Properties. In: Gliński J., Horabik J., Lipiec J. (eds) Encyclopedia of Agrophysics. Springer, Dordrecht

21. Junge, B., Abaidoo, R., Chikoye, D. and Stahr, K. (2008). Soil Conservation in Nigeria: Past and present onstation and on-farm initiatives. Soil and Water Conservation Society, Ankeny, USA.

22. Kar, G. and Kumar, A. (2007). Effects of irrigation and straw mulch on water use and tuber yield of potato in eastern India. Agricultural Water Management, 94(1): 109-116

23. Klute, A. And Dirksen, C. (1986). Hydraulic conductivity and diffusivity: Laboratory methods, pp687-734. Methods of soil analysis Part 1: Physical and Mineralogical Methods, 2nd Edition, American Society of Agronomy-Soil Science Society of America.1188p 
24. Kuo, S. (1996). Phosphorus pp 869-919. In: D. L. Sparks, A. L. Page, P. A. Helmke, R. H. Loeppert, P. N. Soltanpour, M. A. Tabatabai, C. T. Johnston and M. E. Sumner (Editors), Methods of Soil Analysis Part 3, Soil Science Society of America and American Society of Agronomy, Madison, 1390p

25. Linn, J., Hutjens, M. Shaver, R. Howard, W. T. and Kilmer, L. (2018). The ruminant digestive system. https://extension.umn.edu/diary.nutrition/ruminant-digestive -system. (Retrieved on 20th January 2019)

26. London, J. and Walder, C. (2018). Sweet Potatoes are officially one of the best carbs you can eat. https://www.goodhousekeeping.com/health/diet-nutrition/a48026/sweet-potato-nutrition/ (Retrieved on 1st April 2019)

27. Mclean, E. O. (1982). Soil pH and Lime requirement, pp 199-224. In: A. L. Page, R. H. Miller and D. R. Keeney (Editors) Methods of Soil Analysis. Part 2, 2nd edition, Agronomy Monograph 9, American Society of Agronomy, Madison, Wisconsin, 1350p

28. Murphy, J. and Riley, J. P. (1962). A modified single solution method for the determination of phosphate in natural waters. Analytica Chimica Acta, 27: 31-36

29. Nelson, D. W. and L. E. Sommers (1982). Total Carbon, Organic Carbon and Organic Matter, pp 539-579. In: A. L. Page, R. H. Miller and D. R. Keeney (Editors) Methods of Soil Analysis. Part 2, 2nd edition, Agronomy Monograph 9, American Society of Agronomy, Madison, Wisconsin, 1350p

30. Ogban, P. I., Ekanem, T. and Etim, A. E. (2016). Effect of mulching methods on soil properties and growth and yield of maize in southeastern Nigeria. https://www.semanticscholar.org/paper/Effect-of-mulching-methods-onsoil-properties-and-OgbanEkanem/c1e63040360f82b161675d15593082b0ee711525\#paper-header (Retrieved on $12^{\text {th }}$ February, 2020)

31. Ogbodo, E.N. (2011). Assessment of some soil fertility characteristics of Abakaliki Urban Floodplains of Southeast Nigeria, for sustainable crop production. World Journal of Agricultural Sciences, 7 (4): 489-495.

32. Omenihu, A. A. and Opara-Nadi, O. A. (2015). Changes in a tropical Ultisol under different management systems in Southeastern Nigeria: 1. Soil physical and hydrological properties. Nigeria Journal of Soil Science, 25 $70-79$.

33. Peace (2015). Mulching: Boosting Agricultural Output through Soil Improvement.

34. https://www.agronigeria.com.ng/mulching-boosting-agricultural-output-through-soil-improvement/. (Retrieved on April 28 2019)

35. Pypers, P., Verstracte, S., Thi, C. P., Merkx, R. (2005). Changes in mineral nitrogen, phosphorus availability and salt-extractable aluminium following the application of green manure residues in two weathered soils of south Vietnam. Soil Biology and Biochemistry, 37: 163 - 172.

36. Rhoades, J.D. (1996). Salinity: Electrical Conductivity and Total Dissolved Solids, pp417-435 In: D. L. Sparks, A. L. Page, P. A. Helmke, R. H. Loeppert, P. N. Soltanpour, M. A. Tabatabai, C. T. Johnston and M. E. Sumner (Editors), Methods of Soil Analysis Part 3, Soil Science Society of America and American Society of Agronomy, Madison, 1286p

37. Stathers, T., Mwanga, R., Carey, T., Njoku, J., Malinga, J., Njoku, A., (2018). Everything You Ever Wanted to Know about Sweet potato: Reaching Agents of Change ToT Manual. Topic6: Sweet potato Production and Management. International Potato Center. Nairobi (Kenya). ISBN978-92-9060-502-7. 33p

38. Telkar, S. G. Singh, A. K. Kant, K. Solanki, S. P. S., and Kumar, D. (2006). Types of mulching and their uses for dry land condition. Biomolecule Reports.

39. https://www.researchgate.net/publication/320356488 (Retrieved on 3rd May 2019)

40. Thomas, G.W. (1996). Soil pH and Soil Acidity, pp 475-490. In: D. L. Sparks, A. L. Page, P. A. Helmke, R. H. Loeppert, P. N. Soltanpour, M. A. Tabatabai, C. T. Johnston and M. E. Sumner (Editors), Methods of Soil Analysis Part 3, Soil Science Society of America and American Society of Agronomy, Madison, 1390p

41. Udosen, C. E. (2012). Rainfall Trends in Uyo-Akwa Ibom State and its Implication on Urban Flooding. https://www.researchgate.net/publication/276042783_Rainfall_Trends_in_Uyo-Akwa_Ibom_State_and_its_ Implication_on_Urban_Flooding (Retrieved on 5th January 2019) 